\title{
Biofacies and age of Cambrian trilobite associations of the Diringde reef complex (northern Siberian Platform, Russia)
}

\author{
TATYANA V. PEGEL
}

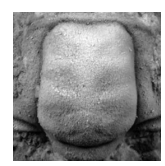

\begin{abstract}
The Diringde reef complex (Kotuy River Basin, Southwest of the Anabar Region, northern Siberian Platform, Russia) has formed during the late mid-Cambrian-early Furongian at the shelf margin of the epicontinental marine basin. Two detached carbonate buildup complexes originated. The southern mid-Cambrian buildup complex is replaced laterally by shale-carbonate rocks of the open basin slope. The northern mid-Cambrian-Furongian buildup complex passes laterally into the inner shelf dolomites. The trilobite associations of the central parts of both buildup complexes consist of rare endemic polymerids, distributed mainly in interbeds between algal buildups. The trilobite associations in narrow facial transition zones (reef flanks) to surrounding stratified deposits differ in having more abundant polymerids, higher taxonomic diversity, and include also agnostoids. The trilobite associations are similar to the assemblage of the reef-dominated mid-Cambrian-Furongian Chukuka Formation that is widespread in the neighboring South Anabar Region. The associations from the reef flank of the southern buildup complex consist mainly of species distributed in Cambrian shallow-water deposits of the Saami, Sakha, Nganasany and Tavgi horizons in the Kulyumbe River reference section, northwestern Siberian Platform. The trilobite assemblages of deeper water deposits of the Eyra Formation that are found on the open marine side of the Diringde reef complex combine typical elements of mainly endemic, shallow-water associations of the southern buildups and the slope basin associations with various cosmopolitan pre-Furongian agnostoids enabling international correlations. $\bullet$ Key words: Cambrian, trilobite associations, Diringde reef complex, biofacies, Siberian Platform.
\end{abstract}

PEGEL, T.V. 2014. Biofacies and age of Cambrian trilobite associations of the Diringde reef complex (northern Siberian Platform, Russia). Bulletin of Geosciences 89(2), 335-345 (9 figures). Czech Geological Survey, Prague. ISSN 1214-1119. Manuscript received February 18, 2013; accepted in revised form March 25, 2014; published online May 5, 2014; issued May 19, 2014.

Tatyana V. Pegel, Siberian Research Institute of Geology, Geophysics and Mineral Resources, Krasny prospect 67, Novosibirsk,630091 Russia; pegel@mail.ru,pegel@sniiggims.ru

The Diringde reef complex of the Cambrian age is located in the basin of the Kotuy River middle course within the Southwest of the Anabar Region (northern Siberian Platform, Russia, see Shishkin et al. 1978, Shishkin \& Pegel 1978, Shishkin 1981, Astashkin et al. 1984). It is characterized by a complicated structure, abrupt sedimentary facies variations, lack of lithological markers and an irregular distribution of endemic fossils. The reef complex formed at the shelf margin of the epicontinental sea basin (Figs 1,2). Together with the adjacent dolomites of the Kyndyn Formation, it represents the outer margin of the carbonate platform. Southward, the complex is replaced by the mid-Cambrian-Furongian rocks of the Eyra Formation deposited on the open-marine basin slope. The Eyra Formation was investigated by Savitsky (1959), who amassed an abundant palaeontological collection, which was studied by Lazarenko and subsequently by the author. The investigation of complicated structure and composition of the Di- ringde reef complex led to location of areas where replacement of carbonate buildups by stratified shale-carbonate rocks of the Eyra Formation was observed, offering an opportunity to estimate fairly precisely the age of the faunal assemblages of the buildups. The Diringde reef complex was formed during the late mid-Cambrian-early Furongian (see also Ivlev 1973, Shishkin et al. 1978).

\section{Geological settings}

The Diringde reef complex consists of two detached carbonate buildup complexes. The southern buildup complex is exposed along the Kotuy River $\mathrm{ca} 2-3 \mathrm{~km}$ upstream of the Diringde River mouth (see Figs 2, 3). The transitional zone (see above) reaches from the south side of this buildup complex to upper slope deposits of the Eyra Formation and is observed along the right tributary of the Kotuy River 


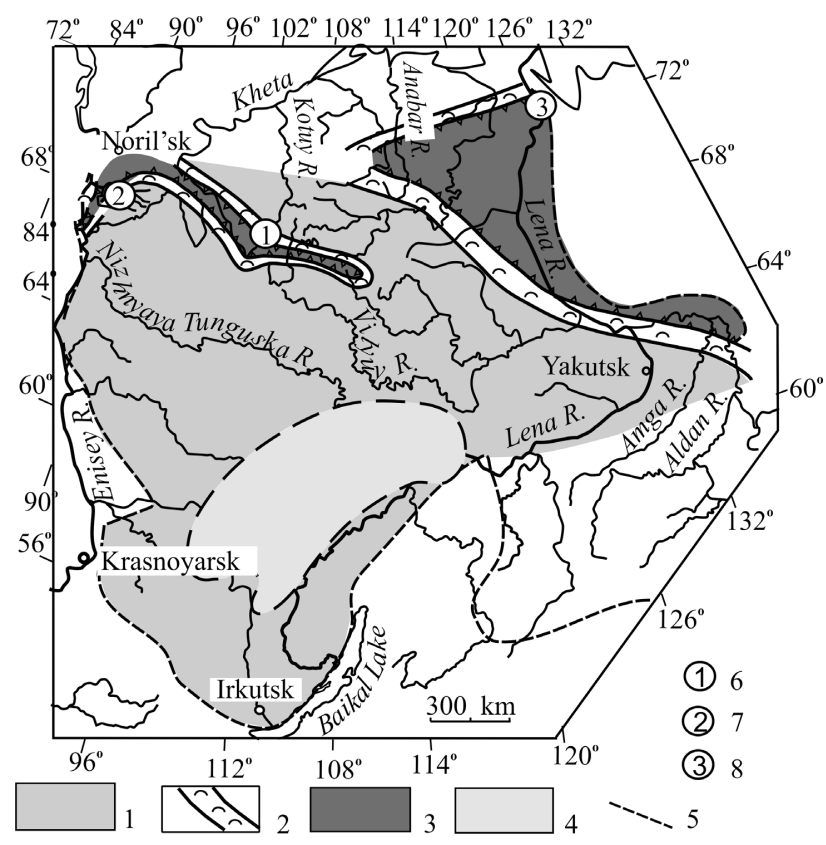

Figure 1. The palaeogeographical scheme of the Siberian Platform. Late Guzhangian-Paibian Stages (modified from Sukhov 1997, fig. 3E). 1 - inner shelf; 2 - open-marine shelf (outer margin of the carbonate platform); 3 - open-marine basin; 4 - dry land; 5 - boundary of the Siberian Platform; 6 - Diringde reef complex; 7 - Kulyumbe River section; 8 - Khos-Nelege River section.

ca $3 \mathrm{~km}$ upstream the mouth of the Diringde River. The overlying deposits are eroded. The relationship and contact with dolomites of the Kyndyn Formation laterally replacing the Diringde reef complex can be observed in the northern buildup complex in the Diringde River mouth.

The central parts (or cores) of each buildup complex are composed of algal limestone bioherms with detrital inter- calations. Narrow zones of facies transition (strata of the reef flanks) exist at the contact of organic buildups and adjacent stratified floatstones/rudstones/grainstones to wackestones.

\section{Distribution of trilobite associations}

A number of trilobite associations were found in the organic buildups, the strata of the Diringde reef flanks and in the rocks of the Eyra Formation (Pegel 1982). The spacious depositional environments (outer margin of the carbonate platform, slope basin and the transitional zone) with corresponding trilobite biofacies (Fig. 2) provide a generalized image of the palaeobiogeographical distribution of trilobite associations.

The trilobite associations of the reef cores consist of polymerids, distributed mainly in interbeds and lenses of platy detrital limestone that fill the space between the algal buildups (Fig. 4). Trilobite associations of the inner parts of the bioherms are generally scarce, monotypic or consist of one to three species with few idividuals. Only occasionally, they can form accumulations. The cranidia of such trilobites are usually highly convex, hemispherical, with a massive glabella, narrow fixigenae and short palpebral lobes. Trilobite associations in the marginal parts of the cores are more abundant and diverse, with forms typical for the reef flank strata. They consist of mainly small or medium-sized cranidia, rare pygidia, librigenae, and thoracic segments which are evenly distributed and randomly oriented. The trilobites from the strata of the reef flank occur in limestone interbeds formed by organic detritus, oolitic platy limestones and calcareous sandstones. They differ from those of the core associations in a greater abundance, a higher

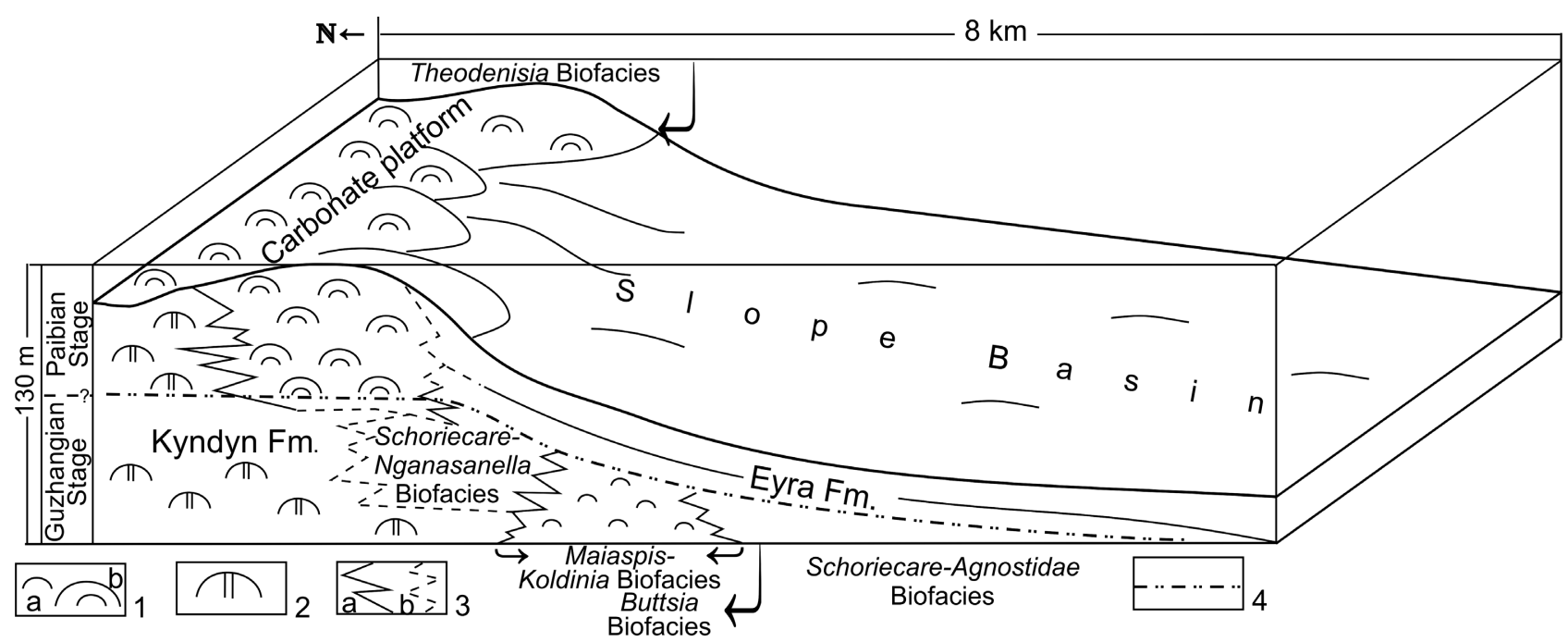

Figure 2. Trilobite biofacies in the Diringde reef complex (modified from Pegel 1989, fig. 1). 1 - algal buildups (a - southern buildup complex; b - northern buildup complex); 2 - dolomitised organic buildups; 3 - lithologic/facies boundaries ( $\mathrm{a}$ - definite; $\mathrm{b}$ - supposed); 4 - supposed mid-Cambrian-Furongian boundary. 
diversity, and include rare agnostoids. The trilobites from the strata of the reef flanks combine elements of the trilobite assemblages of the carbonate platform margin and the slope. Polymerids often have a flattened cranidium, different ratios of glabella and fixigenae, long and curved palpebral lobes, and a long frontal area. The abundance and diversity of the agnostoids increase towards the open marine slope. The absence of complete dorsal exoskeletons and abundant shelly accumulations provide evidence of transportation.

In the southern buildup complex the typical species of the trilobite associations of the reef core (including marginal parts) are Maiaspis inflata Chernysheva in Krys'kov et al., 1960, M. mirabilis Chernysheva, 1956, Buttsia contracta Pegel in Pegel \& Khramova, 1985, Cyclognathina sibirica Gogin, 1990, Munija modesta Khramova, 1980, Seletella borea Pegel, 1989 and Plethopeltidae (Koldinia minor Kobayashi, 1943, Plethopeltoides elegans Khramova, 1968 and Koldiniella sp.) forming the association typical for the Maiaspis-Koldinia Biofacies (see Figs 5A and 6A-I). Typical elements of the trilobite assemblages of the coeval deposits in the reef flanks are Buttsia contracta and B. parvula Khramova, 1977. They are accompanied by species of Bonneterrina Lochman, 1936, Koldinia Walcott \& Resser, 1925, Koldiniella Sivov in Egorova et al., 1955, Plethopeltoides Khramova, 1968, Maiaspis Chernysheva in Chernyscheva et al., 1956, Olenekella Khramova in Pegel \& Khramova, 1985, Onchonotellus Lermontova, 1951, Sacha Rosova, 1964, Schoriecare Rosova, 1964, Seletella Ivshin, 1962, Trinia Poletaeva in Chernysheva et al., 1956, and other polymerids with rare individuals of agnostoids (Buttsia Biofacies, see Figs 5B and 8A-I). The overlying strata of the rear (north) side of the southern buildup complex include Nganasanella interminata Rosova, 1964, N. tavgaensis Rosova, 1963, Catuniella lauta Lazarenko, 1960, Groenwallina decora Rosova, 1964, Pauciella prima (Lazarenko, 1960), Schoriecare compta Pegel, 1989, Ammagnostus simplexiformis (Rosova, 1964), plus species of Coosella Lochman, 1936, Modocia Walcott, 1924, Pesaiella Rosova, 1964, Nericella Rosova, 1964, Koldinia Walcott \& Resser, 1925, Koldiniella Sivov in Egorova et al., 1955, Plethopeltoides Khramova, 1968, Skryjagnostus Šnajdr, 1957 and others (Schoriecare-Nganasanella Biofacies, see Figs 5C and 8J-T).

The trilobite associations from the base of the reef core in the northern buildup complex include Didwudina sp. and some species and genera that also occur in the southern buildup complex, such as: Maiaspis sp., Munija modesta Khramova, 1980, Seletella borea Pegel, 1989 and Koldinia sp. (Maiaspis-Koldinia Biofacies; Figs 5A and 6J-L). In supposedly related strata of the reef flanks, Olimus compactus E. Romanenko in Gogin \& Pegel, 1997, Prismenaspis aff. trisulcata Ergaliev, 1980 and Schoriecare compta Pegel, 1989 occur (Schoriecare-Nganasanella

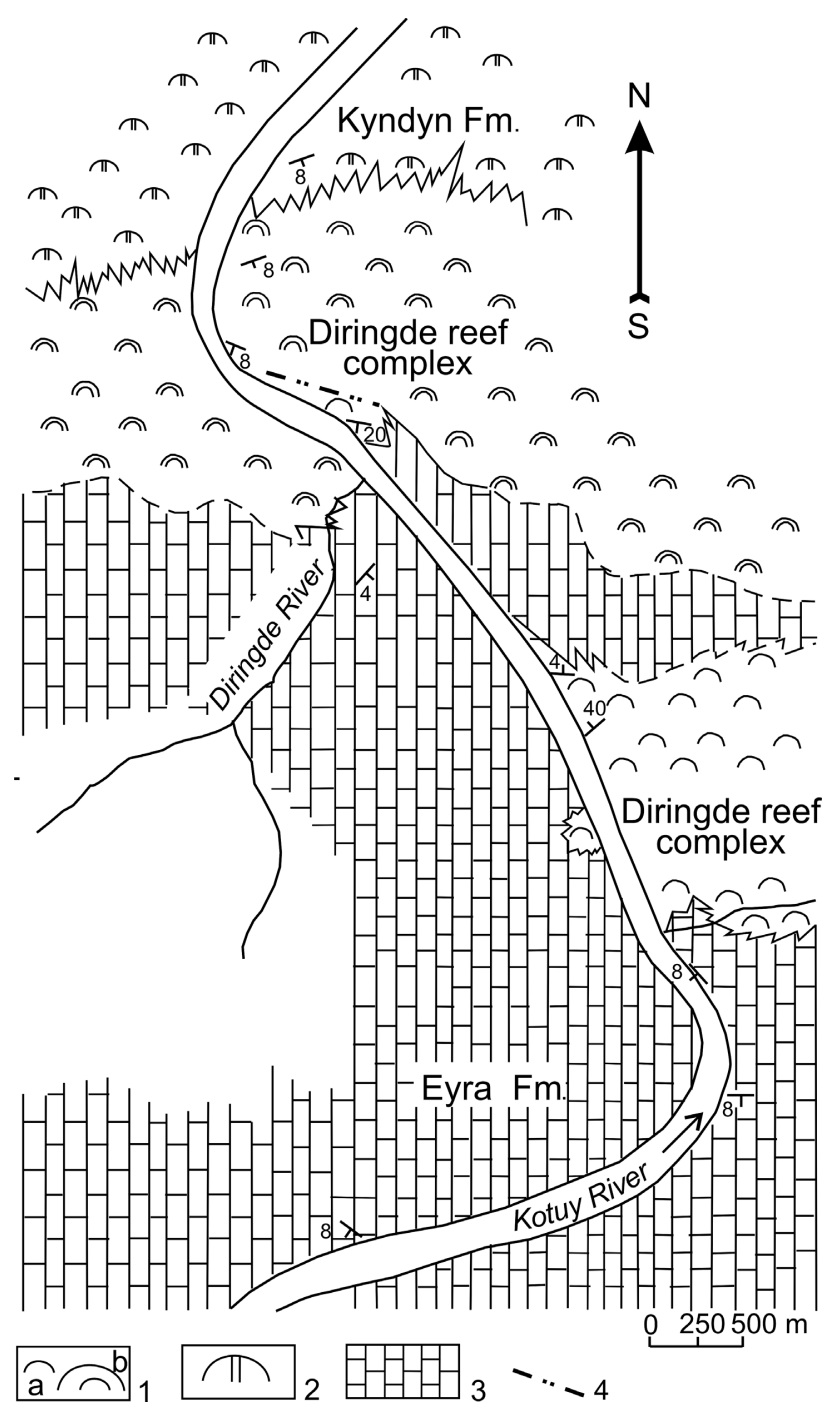

Figure 3. Schematic geological map of the Kotuy River area in the Diringde River mouth area (modified from Shishkin et al. 1978, fig. 1). 1 - algal buildups of the Diringde reef complex [a - southern (mid-Cambrian) buildup complex; b - northern (Furongian buildup complex)]; 2 - dolomitised organic buildups of the Kyndyn Formation; 3 - argillitic-carbonate stratified deposits of the Eyra Formation; 4 - supposed mid-Cambrian-Furongian boundary.

Biofacies; Figs 5C and 8U, V). The trilobite associations in the remainder overlying part of the northern buildup complex differ in their composition. New elements are several species of Theodenisia Clark, 1948 in association with Albansia Howell, 1937 and Ritella Khramova \& Pegel in Pegel \& Khramova, 1985 (Theodenisia Biofacies; Figs 5D, $6 \mathrm{M}-\mathrm{S}$, and $8 \mathrm{~W}-\mathrm{Z}$ ). Theodenisia aff. communis (Rasetti, 1944), Th. glabra Pegel, 1989, Th. dissortis Pegel, 1989, Munija gloriosa Khramova, 1980 and Ritella plena Khramova \& Pegel in Pegel \& Khramova, 1985 are typical species of the middle part of the bioherm. Albansia? ex gr. montanenis Howell \& Duncan, 1939, Seletella subquadrata Pegel, 1989, Munija modesta Khramova, 1980, 


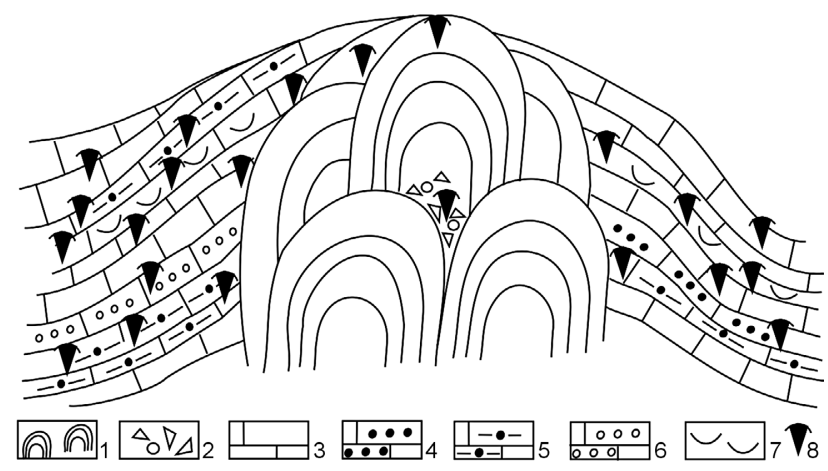

Figure 4. Trilobite distribution in algal buildups and reef flank strata. 1, 2 - algal buildups: 1 - algal bioherms, 2 - detrital intercalations; 3-7 - reef flank strata: 3 - limestone, 4 - calcareous sandstone, 5 - silty limestone, 6 - oolitic limestone, 7 - organic detritus; 8 - trilobites.
Ritella umbonata Khramova \& Pegel in Pegel \& Khramova, 1985 and Theodenisia paulula Khramova, 1977 dominate in trilobite assemblages of the marginal parts of the core and strata of the reef flanks near the frontal (southern) border of the buildup.

\section{Age and correlation}

The trilobite associations of the Diringde reef complex are endemic (particularly on the species level), which provides difficulties for the identification of their precise age. However, the Diringde reef complex is located at the boundary of two palaeoenvironments. The margin of the carbonate platform is composed of shallow-water deposits and has a

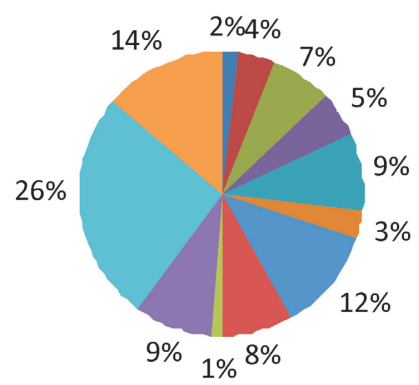

$\begin{array}{ll}\text { Acidaspides } & \text { Agnostidae } \\ \text { Buttsia } & \text { Camaraspis } \\ \text { Cyclognathina } & \text { Didwudina } \\ \text { Maiaspis } & \text { Munija } \\ \text { Onchonotellus } & \text { Seletella } \\ \text { Plethopeltidae } & \text { the rest taxa }\end{array}$

$N=158$

A

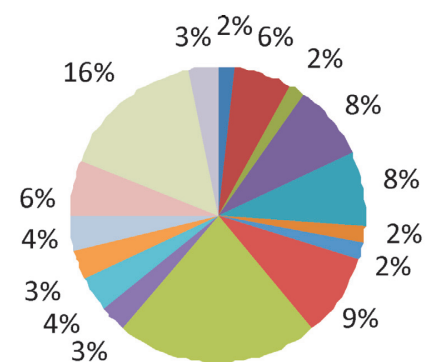

$22 \%$

\section{Acidaspidella \\ - Bonneterrina \\ Coosella \\ - Groenwallina \\ Nganasanella \\ Pauciella \\ Raduginella \\ Plethopeltidae}
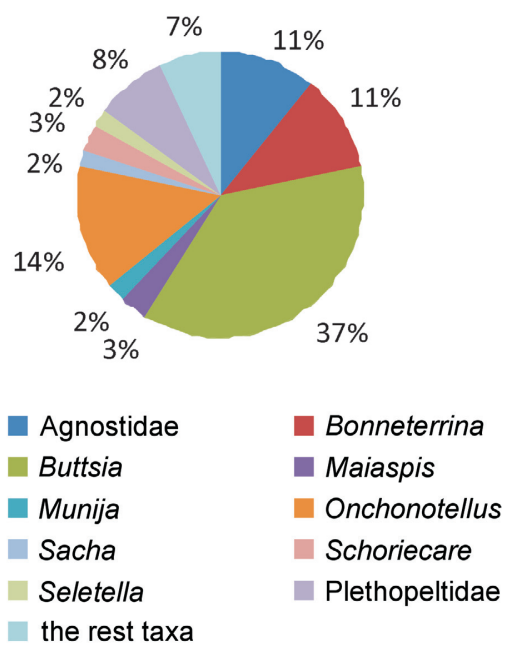

$\mathrm{N}=250$ B

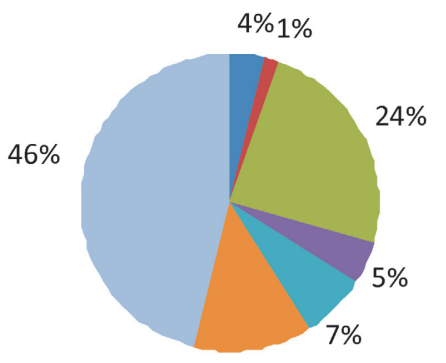

$13 \%$

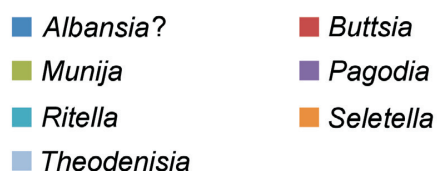

Figure 5. Relative abundances of taxa in the upper mid-Cambrian and Lower Furongian trilobite biofacies of the Diringde reef complex. $\mathrm{N}$ - the total number of individuals. - A Maiaspis-Koldinia Biofacies in the mid-Cambrian reef core of the southern and northern buildup complexes. - B - Buttsia Biofacies in the mid-Cambrian reef flanks of the southern buildup complex. - C - Schoriecare-Nganasanella Biofacies in the mid-Cambrian reef flanks of the southern buildup complex. $\cdot \mathrm{D}-$ Theodenisia Biofacies in the Lower Furongian reef core and reef flanks of the northern buildup complex. 


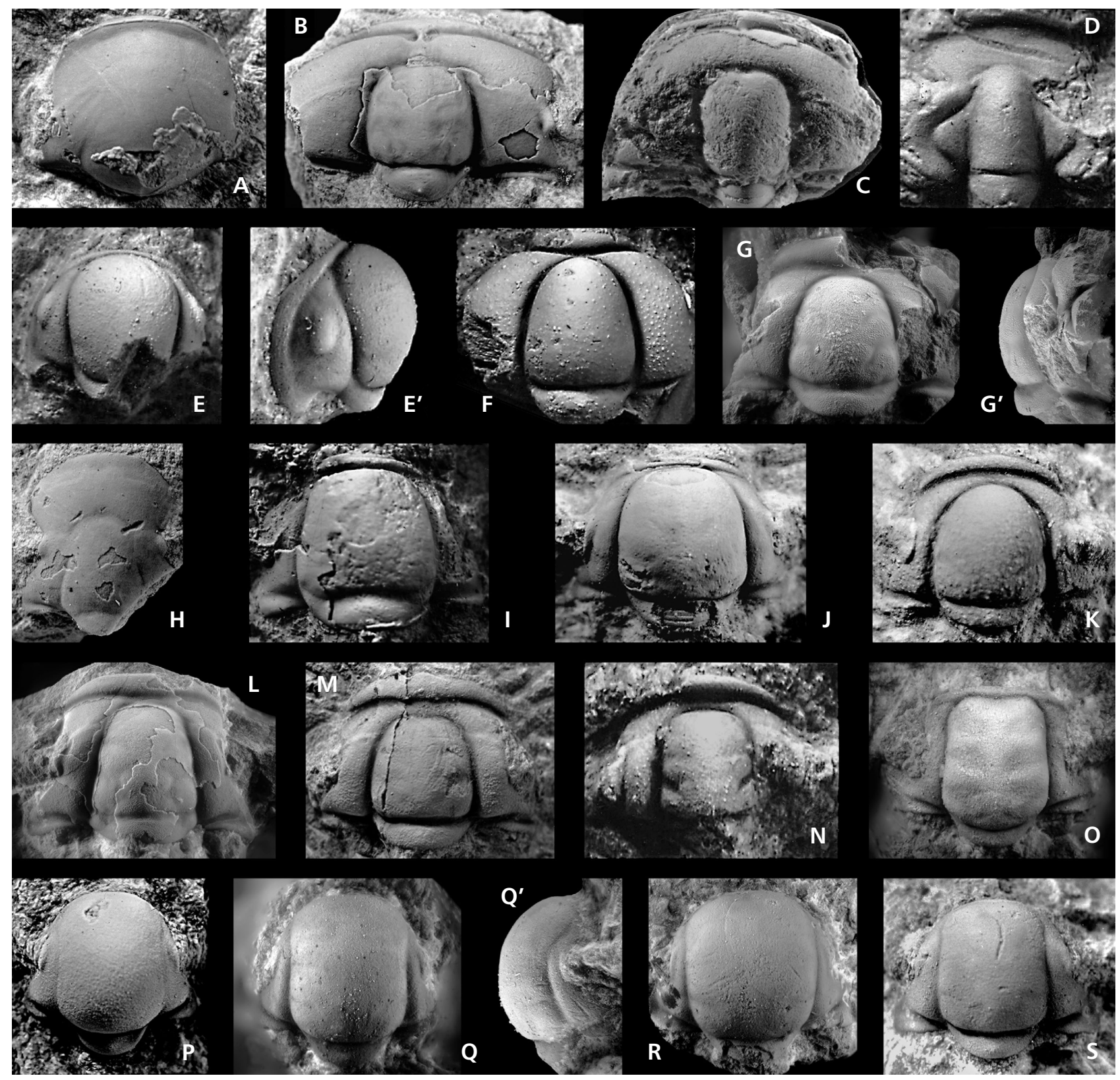

Figure 6. Trilobites of the organic buildups biofacies of the Diringde reef complex. Specimens are reposited at the Siberian Research Institute of Geology, Geophysics and Mineral Resources (SNIIGGiMS) and the Central Siberian Geological Museum (CSGM), Novosibirsk, Russia. - A-L - Mid-Cambrian Maiaspis-Koldinia Biofacies: A - Koldinia minor Kobayashi, 1943, cranidium, × 4.5, SNIIGGiMS, 366/47; B - Maiaspis mirabilis Chernysheva in Chernysheva et al., 1956, cranidium, $\times 2$, SNIIGGiMS, 366/84; C - Maiaspis inflata Chernysheva in Krys'kov et al., 1960, cranidium, $\times$ 5, SNIIGGiMS, 366/224; D - Schoriecare optata (Chernysheva in Krys'kov et al., 1960), cranidium, $\times 10$ SNIIGGiMS, 366/111; E, E' - Buttsia contracta Pegel in Pegel \& Khramova, 1985, cephalon, dorsal and lateral views, $\times 7$, CSGM, collection 878; F - Onchonotellus conusoides Lazarenko, 1968, cranidium, × 6, CSGM, collection 909; G, G' - Munija modesta Khramova, 1980, cranidium, dorsal and lateral views, × 3, SNIIGGiMS, 366/221; H - Plethopeltoides elegans Khramova, 1968, cranidium, × 3, SNIIGGiMS, 366/80; I, J - Seletella borea Pegel, 1989 , cranidia, CSGM, collection 909 (I $-\times 4.5 ; \mathrm{J}-\times 5$ ); K - Didwudina sp., cranidium, $\times 7.5$, SNIIGGiMS, 366/69; L - Munija modesta Khramova, 1980, cranidium, $\times 2.5$, SNIIGGiMS, 366/72. - M-S - Furongian Theodenisia Biofacies: M - Munija gloriosa Khramova, 1980, cranidium, $\times 3$, SNIIGGiMS, 366/74; N - Ritella plena Khramova \& Pegel in Pegel and Khramova, 1985, cranidium, $\times 11$, CSGM, collection 878; O - Theodenisia dissortis Pegel, 1989, cranidium, × 8, SNIIGGiMS, 366/145; P, Q, Q' - Theodenisia glabra Pegel, 1989, cranidia, × 6 (P - CSGM, collection 909; Q - dorsal and lateral views, SNIIGGiMS, 366/148); R - Theodenisia sp., cranidium, $\times 7$, SNIIGGiMS, 366/147; S - Theodenisia aff. communis (Rasetti, 1944), cranidium, × 6.5, CSGM, collection 909 . 


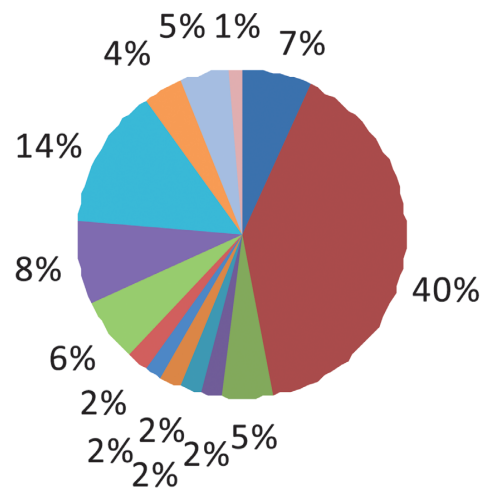

$\begin{array}{ll}\text { Acrocephalites } & \text { Agnostidae } \\ \text { Anomocariopsis } & \text { Bonneterrina } \\ \text { Catuniella } & \text { Paracoosia } \\ \text { Groenwallina } & \text { Nganasanella } \\ \text { Paradamesella } & \text { Sacha } \\ \text { Schoriecare } & \text { Toxotis } \\ \text { Plethopeltidae } & \text { the rest taxa }\end{array}$

\section{$N=2180$}

Figure 7. Relative abundances of taxa in collections from mid-Cambrian Schoriecare-Agnostidae Biofacies in open marine deposits of the Eyra Formation. $\mathrm{N}-$ the total number of individuals.

predominantly endemic fauna, whereas the open marine slope facies is characterized by faunal elements, which indicate far-reaching biogeographical relationships.

Structures similar to those of the Diringde reef complex are distributed on the southwestern slope of the Anabar antecline. These are characterized by a distinctive Chukuka faunal assemblage, the age of which has been discussed for a long time. Alternative interpretations favoured either a late mid-Cambrian-early Furongian age (Kaban'kov 1966; Kuteynikov et al. 1976; Khramova 1977, 1980) or an age corresponding with the younger half of the Furongian (Gogina et al. 1966).

The trilobite associations of the cores and the nearest parts of the reef flank strata of the Diringde reef complex include Maiaspis inflata, Plethopeltoides elegans, Munija modesta, Theodenisia paulula and are similar to fauna assemblages of the reefal Chukuka Formation in the neighboring South Anabar region. This indicates the facies connection of the Chukuka faunal assemblage with the reef deposits described herein.

The associations from the strata in the reef flanks of the southern buildup complex mainly consist of species distributed in the Labazny and Orakta formations in the Kulyumbe River section of the northwestern Siberian Platform. Those associations of the Kulyumbe River area include Ammagnostus simplexiformis (Rosova, 1964), Bonneterrina saamica Rosova, 1964, B. sachaica Rosova, 1964, Sacha perexigua (Rosova 1964), Belovia aliquantula Rosova, 1964, Acidaspidella limata Rosova, 1963, Acrocephalella granulosa Rosova, 1963, Nericella diffusa Rosova, 1964, Pauciella prima (Lazarenko, 1960), Groenwallina decora Rosova, 1964, Nganasanella nganasanensis Rosova, 1963, N. tavgaensis Rosova, 1963, Catuniella lauta Lazarenko, 1960 as well as species of Schoriecare Rosova, 1964, Pesaiella Rosova, 1964, Modocia Walcott, 1924, and Camaraspis Ulrich \& Resser in Ulrich, 1924. The Kulyumbe River section is typical for shallow-water deposits of the open-marine and inner shelves. The trilobites listed above are distributed in the Saami, Sakha, Nganasany and Tavgi horizons of this section (Rosova 1964). In the Russian stratigraphical scale (Anonymous 1983, Astashkin et al. 1991) deposits of the Saami and Sakha horizons are correlated with the upper part of the Mayan Regional Stage. The Nganasany and Tavgi horizons are assigned to the Ayusokkanian Regional Stage. This stage is correlated with the upper part of the global Guzhangian Stage. A.V. Rosova suggested that lower boundary of the Nganasany Horizon can be compared with the base of the Glyptagnostus reticulatus Zone (Rosova 1968, 1984, etc.) and thus the lower boundary of the Furongian.

The trilobite associations of the deeper water deposits of the Eyra Formation on the seaward side of the Diringde reef complex have typical elements of the predominantly endemic shallow-water shelf associations of the southern buildup complex (Bonneterrina sachaica, Trinia cf. bella, Munija modesta, Groenwallina decora, Catuniella lauta, Plethopeltoides elegans, Schoriecare compta, Sacha

Figure 8. Trilobites of the reef flank biofacies of the Diringde reef complex. Specimens are reposited at the Siberian Research Institute of Geology, Geophysics and Mineral Resources (SNIIGGiMS) and the Central Siberian Geological Museum (CSGM), Novosibirsk, Russia. • A-I - Buttsia Biofacies: A - Buttsia contracta Pegel in Pegel \& Khramova, 1985, cranidium, × 5.5, CSGM, collection 909; B - Buttsia parvula Khramova, 1977, cranidium, × 10, SNIIGGiMS, 366/230; C - Schoriecare sp., cranidium, × 3.5, SNIIGGiMS, 366/27; D - Maiaspis mirabilis Chernysheva, 1956, cranidium, × 6, SNIIGGiMS, 366/85; E - Plethopeltoides elegans Khramova, 1968, cranidium, × 3.5, SNIIGGiMS, 366/168; F - Koldinia infima Lazarenko, 1968, cranidium, × 3, SNIIGGiMS, 366/46; G - Seletella subquadrata Pegel, 1989, cranidium, × 7.5, SNIIGGiMS, 366/152; H - Olenekella alimbata Khramova \& Pegel in Pegel \& Khramova, 1985, damaged cranidium, $\times$ 5.5, SNIIGGiMS, 366/94; I - Bonneterrina saamica Rosova, 1964, cranidium, $\times$ 4, SNIIGGiMS, 366/301. - J-V - Schoriecare-Nganasanella Biofacies: J - Nganasanella tavgaensis Rosova, 1963, cranidium, $\times 10$, SNIIGGiMS, 366/61; K - Nganasanella interminata Rosova, 1964, cranidium, × 5, CSGM, collection 909; L - Catuniella lauta Lazarenko, 1960, cranidium, $\times 10.5$, SNIIGGiMS, 366/116; M - Schoriecare compta Pegel, 1989, cranidium, × 4.5, CSGM, collection 909; N - Groenwallina decora 


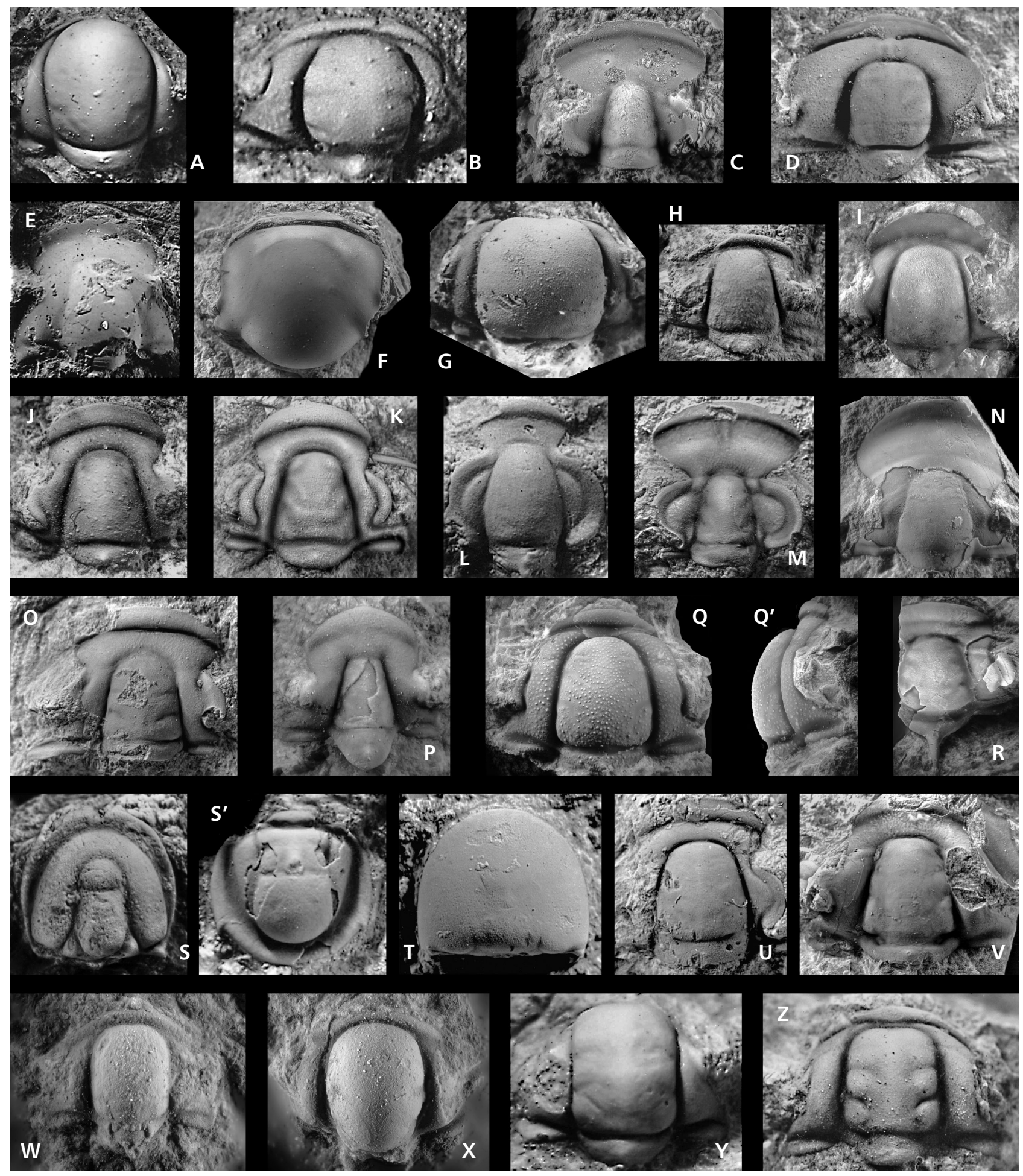

Rosova, 1964, cranidiun, × 4, SNIIGGiMS, 366/24; O - Nericella diffusa Rosova, 1964, cranidium, × 4, SNIIGGiMS, 366/118; P - Pauciella prima (Lazarenko, 1960), cranidium, $\times$ 10, SNIIGGiMS, 366/28; Q, Q' - Modocia sp., cranidium, dorsal and lateral views, $\times 3$, SNIIGGiMS, 366/31; $\mathrm{R}-$ Pesaiella sp., partial cranidium, $\times 2$, SNIIGGiMS, 366/26; S, S' - Ammagnostus simplexiformis (Rosova, 1964): S - cephalon, $\times 5.5$, SNIIGGiMS, 366/36, S' - pygidium, $\times$ 6.5, SNIIGGiMS, 366/35; T - Skryjagnostus sp., cephalon, $\times$ 4.5, SNIIGGiMS, 366/30; U - Olimus compactus E. Romanenko in Gogin \& Pegel, 1997, partial cranidium, $\times$ 4.5, SNIIGGiMS, 366/76; V - Prismenaspis aff. trisulcatus Ergaliev, 1980, damaged cranidium, $\times 3$, SNIIGGiMS, 366/64. $\bullet$ W-Z - Theodenisia Biofacies: W, X - Albansia? ex gr. montanensis Howell \& Duncan, 1939, cranidia (W $-\times 13$, SNIIGGiMS, 366/10; X - × 10, SNIIGGiMS, 366/79); Y - Theodenisia paulula Khramova, 1977, cranidium, $\times 10$, SNIIGGiMS, 366/149; Z - Ritella umbonata Khramova \& Pegel in Pegel \& Khramova, 1985, cranidium, × 9.5, CSGM, collection 878. 


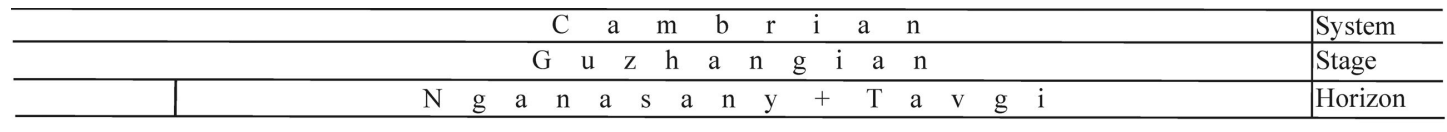

$\begin{array}{llllllllllllll}\text { E } & \text { y } & \mathrm{r} & \mathrm{a} & \mathrm{F} & \mathrm{o} & \mathrm{r} & \mathrm{m} & \mathrm{a} & \mathrm{t} & \mathrm{i} & \mathrm{o} & \mathrm{n}\end{array}$
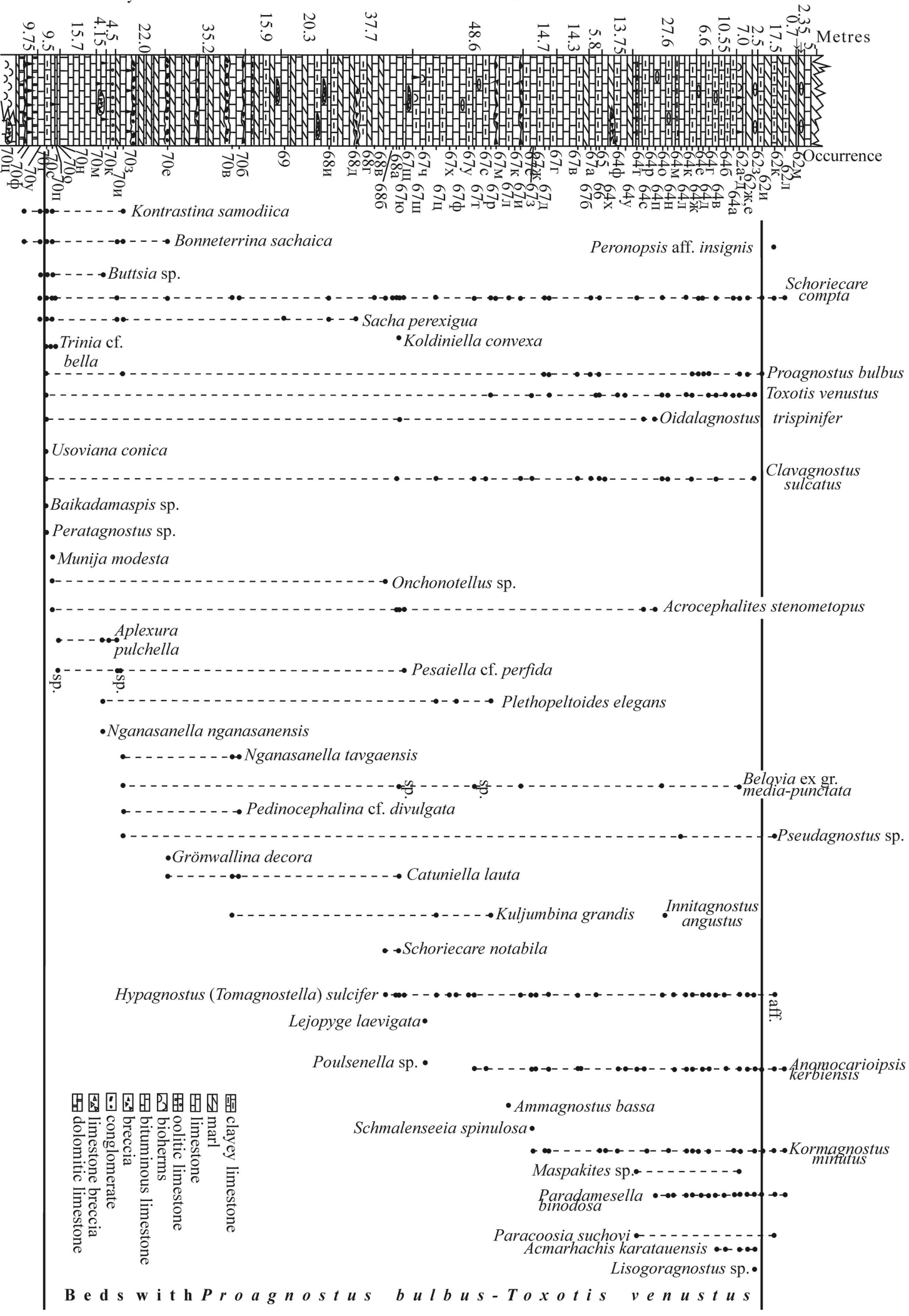
perexigua, and others) and slope basin assemblages with various cosmopolitan agnostoids (Figs 7 and 9). These cosmopolitan agnostoids occur together with agnostoids of the Guzhangian Stage in the Ogon'or Formation along the Khos-Nelege River in the north-eastern part of the Siberian Platform and includes Proagnostus bulbus (Butts, 1926), Oidalagnostus trispinifer Westergård, 1946, Clavagnostus sulcatus Westergård, 1946, Hypagnostus sulcifer Wallerius, 1895, Lejopyge laevigata (Dalman, 1828), Ammagnostus bassa Öpik, 1967, and Kormagnostus minutus (Schrank, 1975), see Lazarenko et al. (2008) and Pegel (2010).

Available data confirm a late Guzhangian and pre-Furongian age of the Nganasany and Tavgi horizons of the northwestern Siberian Platform. Consequently, the trilobite associations of the southern buildup complex of the Diringde reef complex, which are linked with the midCambrian deposits of the Eyra Formation, must have the same age.

Trilobite associations of the northern and southern buildup complexes differ strongly. The southern buildup associations comprise mainly Siberian species, whereas associations of the northern buildup predominantly contain species of genera, which are known from different regions of the earth. Among them are Theodenisia Clark, 1948, Albansia Howell, 1937 and Buttsia Wilson, 1951 that all occur mainly in the Furongian of North America, plus Seletella Ivshin, 1962, Didwudina Ivshin, 1962 and Prismenaspis Henderson, 1976 that are known from the Furongian of Kazakhstan. This trilobite assemblage clearly indicates a Furongian age of the northern buildup complex. The presence of some species that occur in the mid-Cambrian southern buildup complex (Munija modesta, M. gloriosa, Seletella subquadrata, S. borea) in the Furongian trilobite associations suggests that the northern buildups were formed at the beginning of the Furongian.

\section{Conclusions}

The trilobite associations of the cores and reef flank strata of the Diringde reef complex are both taxonomically diverse and endemic. Trilobite associations of the cores and the adjacent parts of the reef flank strata of the southern and northern buildups are similar to the mid-Cambrian-early Furongian Chukuka faunal assemblage of the Siberian Platform. The trilobite associations of the reef flank strata in the southern buildup complex include taxa which also

Figure 9. Stratigraphic distribution of trilobites in the lower Eyra Formation in the middle reach of the Kotuy River (by Savitsky, Lazarenko \& Pegel; modified from Pegel 2010, fig. 3). occur in the trilobite assemblages of the Saami, Sakha, Nganasany and Tavgi horizons of the Kulyumbe River section, which typifies the Cambrian shallow-water shelf deposits of the Siberian Platform. The trilobite associations in the lower part of the Eyra Formation along the seaward side of the Diringde reef complex combine species of the shallow water type (present in the Saami, Sakha, Nganasany and Tavgi horizons of the Kulyumbe River reference section) and agnostoids of the slope facies known from the Guzhangian in the Khos-Nelege River section, which is typical for the Cambrian open-marine basin deposits of the Siberian Platform. The available data confirm the preFurongian age of the Nganasany and Tavgi horizons.

\section{Acknowledgments}

Boris B. Shishkin, Alexander B. Fedorov, and L. Dymkina are acknowledged for assisting in collecting specimens from the Diringde reef complex during the expedition in 1976 and sharing their knowledge on the Cambrian geology of the northern Siberian Platform. The Eyra Formation was studied in 1956 by Vladimir E. Savitsky who kindly provided the author with the trilobites from his collection for research. Elena A. Fedorova and Pavel V. Fomin are thanked for photographing the trilobites. I am greatly indebted to the reviewers of the manuscript for their comments and improving the English text. My particular gratitude is to Gerd Geyer, Bayerische Julius-Maximilians-Universität Würzburg, Germany, who provided detailed, very helpful review and useful recommendations.

\section{References}

AnONYMOus 1983. Resulutions of All-Union stratigraphical meeting on the Proterozoic, Palaeozoic and Quaternary of Middle Siberia, Part 1 (Upper Proterozoic and Lower Palaeozoic). 216 pp. Izdatel'stvo SNIIGGiMS, Novosibirsk. [in Russian]

Astashkin, V.A., Pegel, T.V., Shabanov, Y.Y., Sukhov, S.S., Sundukov, V.M., Repina, L.N., Rozanov, A.Y. \& ZhuravLEv, A.Y. 1991. The Cambrian System of the Siberian Platform. 133 pp. International Union of Geological Sciences, Publication No 27.

Astashin, V.A., Varlamov, A.I., Shishrin, B.B \& Fedorov, A.B. 1984. Chukuka barier reef complex, 63-74. In AstASHKIN, V.A. (ed.) Geologiya i perspektivy neftegazonosnosti rifovykh sistem kembriya Sibirskoy platformy. Izdatel'stvo Nedra, Moskva. [in Russian]

ButTs, C. 1926. The Palaeozoic rocks, 41-230. In AdAms, G.I., Butts, C., Stephanson, L.W. \& Cooke, W. (eds) Geology of Alabama. Geological Survey of Alabama Special Report 14, $1-312$.

Chernysheva, N.E., Egorova, L.I., Ogienko, L.V., Poletaeva, O.K. \& RePinA, L.N. 1956. Materials on Palaeontology. New families and genera. Class Trilobita. Trudy Vsesoyuznogo 
nauchnogo-issledovatel'skogo geologicheskogo instituta (VSEGEI), New Series 12, 145-182. [in Russian]

Clark, T.H. 1948. Theodenisia, new name, replacing Denisia Clark. Journal of Paleontology 22, 643.

Dalman, J.W. 1828. Arsberättelse om nyare zoologiska arbeten och upptäcker, till Konglige Vetenskaps-Academiens Embetsmän den 31 mars 1828.138 pp. P.A. Norstedt \& Söner, Stockholm.

Egorova, L.I., Lomovitskaya, M.P., Poletaeva, O.K. \& Sivov, A.G. 1955. Class Trilobita, Trilobites, 102-145. In KHALFIN, L.L. (ed.) Atlas of index forms of fossil faunas and floras of Western Siberia 1. 501 pp. Gosgeoltechizdat, Moscow. [in Russian]

Ergaliev, G.K. 1980. Middle and Upper Cambrian trilobites from Maly Karatau. 211 pp. Akademiya nauk Kazakhskoi SSR, Alma-Ata. [in Russian]

Gogin, I.Y. 1990. New Late Cambrian trilobites from SetteDaban. Ezhegodnik Vsesoyuznogo paleontologicheskogo obshchestva 33, 140-152. [in Russian]

Gogin, I.Y. \& Pegel, T.V. 1997. Middle and Upper Cambrian trilobites from the western part of Sette-Daban, 100-132. In Koren', T.N. (ed.) Atlas of the zonal complexes of leading groups of early Palaeozoic fauna in northern Russia. 212 pp. VSEGEI, St. Pertersburg. [in Russian]

Gogina, N.I., Leonov, B.N. \& Pokrovskaya, N.V. 1966. Once again to the question of the Chukuka Formation and about the regional discordance in the sequence of the Upper Cambrian strata. Uchenye zapiski Nauchno-issledovatel'skogo instituta geologii Arktiki, Regionalnaya geologiya 9, 88-94. [in Russian]

Henderson, R.A. 1976. Upper Cambrian (Idamean) trilobites from western Queensland, Australia. Palaeontology 19, 325-364.

Howell, B.F. 1937. Cambrian Centropleura vermontensis fauna of northwestern Vermont. Bulletin of the Geological Society of America 48, 1147-1210.

Howell, B.F. \& Duncan, D. 1939. Middle-Upper Cambrian transition faunas of North America. Bulletin of the Wagner Free Institute of Science 14(1), 1-11.

IvLEv, N.F. 1973. New data on the stratigraphy of the Cambrian dolomite series of the South-West Prianabar area, 17-22. In Mecnikov, N.V. \& KhomenKo, A.V. (eds) Novye dannye po geologii $i$ neftegazonosnosti Sibirskoy platformy. Trudy SNIIGGiMS 167. [in Russian]

Ivshin, N.K. 1962. Upper Cambrian trilobites of Kazakhstan. Part 2. 412 pp. Akademia nauk Kazakhskoy SSR, Alma-Ata. [in Russian]

Kaban'Kov, V.Y. 1966. On the boundary of the Middle and Upper Cambrian Series in the Siligir River basin (right tributary of the Olenek River). Uchenye zapiski Nauchno-issledovatel'skogo instituta geologii Arktiki, Regionalnaya geologiya 9, 57-77. [in Russian]

Khramova, A.P. 1968. Plethopeltoides Khramova gen. nov. from Upper Cambrian deposits of the northern Siberian Platform. Uchenye zapiski Nauchno-issledovatel'skogo instituta geologii Arktiki, Paleontologiya i biostratigrafiya (NIIGA) 21, 44-49. [in Russian]
Khramova, A.P. 1977. New species of the Upper Cambrian Trilobites of the Siberian Platform, 65-67. In Stukalina, G.A. (ed.) Novye vidy drevnikh rasteniy i bespozvonochnykh SSSR. Izdatel'stvo Nauka, Moskva. [in Russian]

Khramova, A.P. 1980. New Upper Cambrian trilobites of Yakutia, 166-171. In VASILENKo, V.P. et al. (eds) Novye rody $i$ vidy drevnikh rasteniy i bespozvonochnykh SSSR. Izdatel'stvo Nedra, Leningrad. [in Russian]

Kobayashi, T. 1943. Cambrian faunas of Siberia. Journal of the Faculty of Science of the Imperial University of Tokyo 2, Geology 6, 271-334.

Krys'kov, L.N., Lazarenko, N.P., Ogienko, L.V. \& ChernySHEvA, N.E., 1960. New early Palaeozoic trilobites of Eastern Siberia and Kazakhstan, 211-255. In MARKOvskIY, B.P. (ed.) Novye vidy drevnikh rasteniy i bezpozvonovhnykh SSSR 2. [in Russian]

Kuteynikov, E.S., Lazarenko, N.P. \& Mikhaylov, M.V. 1976. Chukuka association of trilobites in the Middle Cambrian strata of the Maya River, 176-183. In Zabaluev, V.V. (ed.) Geologicheskoe stroenie $i$ voprosy neftegazonosnosti Yakutskoy ASSR. Trudy VNIGRI 385. [in Russian]

LAZARENKO, N.P. 1960. Some Upper Cambrian trilobites from the northwestern Siberian Platform. Sbornik statei po paleontologii i piostratigrafii (NIIGA) 20, 12-44.

LAZARENKo, N.P. 1968. New trilobites from the Cambrian deposits of northern Siberia. Trudy Nauchno-issledovatel'skogo instituta geologii Arktiki 155, 176-202. [in Russian]

Lazarenko, N.P., Gogin, I.Y., Pegel, T.V., Sukhov, S.S., Abaimova, G.P., Egorova, L.I., Fedorov, A.B., Raevskaya, E.G. \& Ushatinskaya, G.T. 2008. Excursion 1b. Cambrian stratigraphy of the northwestern Siberian Platform and potential stratotypes of lower boundaries of the proposed Upper Cambrian Chekurovian and Nelegerian stages in the Ogon'or Formation section at the Khos-Nelege River; the boundaries are defined by the FADs of Agnostotes orientalis and Lotagnostus americanus, 60-139. In RozAnOv, A.Y. \& VARLAmov, A.I. (eds) The Cambrian System of the Siberian Platform. Part 2: North-east of the Siberian Platform. PIN RAS, Moscow \& Novosibirsk.

LeRmontova, E.V. 1951. Upper Cambrian trilobites and brachiopods from Boshchekul (NE Kazakhstan). 49 pp. Vsesoyuzniy Nauchno-issledovatelskiy geologicheskiy institut (VSEGEI), Gosudarstvennoe izdatel'stvo, Moscow.

Lochman, C. 1936. New trilobite genera from the Bonneterre Dolomite (Upper Cambrian) of Missouri. Journal of Paleontology $10,35-43$.

ÖPIK, A.A. 1967. The Mindyallan fauna of north-western Queensland. Bureau of Mineral Resources Geology \& Geophysics Australia Bulletin 74, 1-404 and 1-167 (2 vols).

Pegel, T.V. 1982. The distribution pattern of trilobite communities in the Diringde Reef Complex (Cambrian of the SouthWest Prianabar area), 82-89. In Astashrin, V.A. (ed.) Stratigrafiya $i$ fatsii osadochnykh basseynov Sibiri. Izdatel'stvo SNIIGGiMS, Novosibirsk. [in Russian]

Pegel, T.V. 1989. The trilobite biofacies in the Diringde reef complex of Cambrian in the South-West Prianabar area, 20-34. In Bulynnikova, S.P. \& Yadrenkina, A.G. (eds) Bio- 
fatsialniy analiz pri paleogeograficheskikh rekonstruktsiyakh. Izdatel'stvo SNIIGGiMS, Novosibirsk. [in Russian]

Pegel, T.V. 2010. A correlation of the late Middle Cambrian different facies deposits of the type sections of the Siberian Platform, 110-123. In Budnikov, I.V. \& Kraevskiy, B.G. (eds) Regionalnaya geologiya, stratigrafiya $i$ paleontologiya dokembriya $i$ nizhnego paleozoya Sibiri. Izdatel'stvo SNIIGGiMS, Novosibirsk. [in Russian]

Pegel, T.V. \& Khramova, A.P. 1985. Trilobites from the Chukuka lithofacial complex on the Siberian Platform, 37-46. In Astashrin, V.A. (ed.) Stratigraphia i paleontologia prekembria $i$ phanerozoa Sibirii. Izdatel'stvo SNIIGGiMS, Novosibirsk. [in Russian]

RASETTI, F. 1944. Upper Cambrian trilobites from the Levis Conglomerate. Journal of Paleontology 18, 229-258.

Rosova, A.V. 1963. A biostratigraphic scheme for the Upper and upper Middle Cambrian and new Upper Cambrian trilobites. Geologiya i geofizika 9, 3-19.

Rosova, A.V. 1964. Biostratigraphy and descriptions of Middle and Upper Cambrian trilobites of the northwestern Siberian Platform. 148 pp. Izdatel'stvo Nauka, Moscow. [in Russian]

Rosova, A.V. 1968. Biostratigrafiya i trilobity verkhnego kembriya i nizhnego ordovika severo-zapada Sibirskoy platformy. 196 pp. Trudy Instituta geologii i geofiiziki Sibirskogo otdeleniya Akademii nauk SSSR 36. Izdatel'stvo Nauka, Moskva. [in Russian; English translation 1984. Biostratigraphic zoning and trilobites of the Upper Cambrian and Lower Ordovician of the Northwestern Siberian Platform. 243 pp. Amerind Publishing Co., New Delhi.]

Rosova, A.V. 1984. Cambrian. Upper Series, 46-50. In ArkHIPOV, S.A. et al. (eds) Fanerozoy Sibiri, 1. Vend, paleozoy. Izdatel'stvo Nauka, Novosibirsk. [in Russian].

SAvitsky, V.E. 1959. Cambrian. South-West slope of the Anabar uplift, 103-115. In Tкаснеnко, B.V. (ed.) Stratigrafiya siniyskikh i kembriyskikh otlozheniy severo-vostoka Sibirskoy platformy. Trudy NIIGA 101. Gostoptekhizdat, Leningrad. [in Russian]

SHISHKIn, B.B. 1981. The structure of Middle-Upper Cambrian Diringde reef complex of Southwestern Prianabar area, 128-131. In Trofimuk, A.A. \& Kontorovich, A.E. (eds)
Litologiya i geokhimiya neftegazonosnykh tolshch Sibirskoy platformy. Izdatel'stvo Nauka, Moskva. [in Russian]

Shishkin, B.B. \& PEGEL, T.V. 1978. On stratigraphy of the Cambrian dolomite series in the middle course of the Kotuy River (South-West Prianabar area), 36-44. In RePINA, L.N. \& TESAKov, Y.I. (eds) Novoye $v$ stratigrafii $i$ paleontologii nizhnego paleozoya Sredney Sibiri. Institut geologii i geofiziki Siberskogo otdeleniya Academii nauk SSSR, Novosibirsk. [in Russian]

Shishrin, B.B., Pegel, T.V. \& Fedorov, A.B. 1978. The structure of Middle-Upper Cambrian reef-depositional complex of Southwestern Prianabar area, 34-44. In KRASNOv, V.I. (ed.) Aktualnye voprosy regionalnoy geologii Sibiri. Izdatel'stvo SNIIGGiMS, Novosibirsk. [in Russian]

SHRANK, E. 1975. Kambrische Trilobiten der China-Kollektion v. Richthofen. Teil 2. Die Fauna mit Kaolishania? quadriceps von Saimaki. Zeitschrifte geologischen Wissenschaften Berlin 3(5), 591-619.

ŠNAJDR, M. 1957. On new trilobites of the Cambrian of Bohemia. Věstník Ústředního ústavu geologického 32, 235-244.

SuKHOv, S.S. 1997. Cambrian depositional history of the Siberian craton: evolution of the carbonate platforms and basins. Sedimentary Facies and Palaeogeography 15(5), 27-39.

UlRICH, E.O. 1924. Notes on new names in table of formations and on physical evidence of breaks between Paleozoic systems in Wisconsin. Transactions of the Wisconsin Academy of Sciences, Arts and Letters 21, 71-107.

WalcotT, C.D. 1924. Cambrian and Lower Ozarkian trilobites. Smithsonian Miscellaneous Collections 75, 53-60.

WalcotT, C.D. \& Resser, C.E. 1925. Trilobites from the Ozarkian sandstones of the island of Novaya Zemlya. Reports of the Scientific Results of the Norwegian Expedition to Novaya Zemlya 1921 24, 1-14.

WALlERIUS, I.D. 1895. Undersökningar öfver zonen med Agnostus laevigatus i Vestergötland, jämpte en inledante öfversikt af Vestergötlands samtliga Paradoxideslager. Gleerupska Universitets-Bokhandeln, Lund, 1-72.

Westergård, A.H.1946. Agnostidae of the Middle Cambrian of Sweden. Sveriges Geologiska Undersökning, Avhandlingar och uppsatser, Series C 477, 40(1), 1-140.

Wilson, J.L. 1951. Franconian trilobites of the central Appalachians. Journal of Paleontology 25, 617-654. 